\title{
Ehrlichioses: An Important One Health Opportunity
}

\author{
Tais B. Saito * and David H. Walker
}

Department of Pathology, University of Texas Medical Branch at Galveston, Galveston, TX 77555, USA;

dwalker@utmb.edu

* Correspondence: tbsaito@utmb.edu; Tel.: +1-1409-772-4813

Academic Editor: Ulrike Munderloh

Received: 15 July 2016; Accepted: 25 August 2016; Published: 31 August 2016

\begin{abstract}
Ehrlichioses are caused by obligately intracellular bacteria that are maintained subclinically in a persistently infected vertebrate host and a tick vector. The most severe life-threatening illnesses, such as human monocytotropic ehrlichiosis and heartwater, occur in incidental hosts. Ehrlichia have a developmental cycle involving an infectious, nonreplicating, dense core cell and a noninfectious, replicating reticulate cell. Ehrlichiae secrete proteins that bind to host cytoplasmic proteins and nuclear chromatin, manipulating the host cell environment to their advantage. Severe disease in immunocompetent hosts is mediated in large part by immunologic and inflammatory mechanisms, including overproduction of tumor necrosis factor $\alpha$ (TNF- $\alpha$ ), which is produced by CD8 T lymphocytes, and interleukin-10 (IL-10). Immune components that contribute to control of ehrlichial infection include CD4 and CD8 T cells, natural killer (NK) cells, interferon- $\gamma$ (IFN- $\gamma$ ), IL-12, and antibodies. Some immune components, such as TNF- $\alpha$, perforin, and CD8 T cells, play both pathogenic and protective roles. In contrast with the immunocompetent host, which may die with few detectable organisms owing to the overly strong immune response, immunodeficient hosts die with overwhelming infection and large quantities of organisms in the tissues. Vaccine development is challenging because of antigenic diversity of E. ruminantium, the necessity of avoiding an immunopathologic response, and incomplete knowledge of the protective antigens.
\end{abstract}

Keywords: Ehrlichia canis; Ehrlichia chaffeensis; Ehrlichia ewingii; Ehrlichia muris; Ehrlichia ruminantium; canine ehrlichiosis; human ehrlichiosis; heartwater; immunopathology; mouse models

\section{Introduction}

Ehrlichiae are obligately intracellular bacteria that are maintained in natural cycles involving a persistently infected vertebrate host and a tick vector. In addition to wildlife reservoir hosts- such as white-tailed deer, African ruminants, carnivores, and rodents-there are incidental hosts: domestic livestock, companion animals, and humans. Infections appear to be subclinical in natural hosts, and the most severe life-threatening illnesses, such as human monocytotropic ehrlichiosis and heartwater, occur in incidental hosts. Understanding the biology of persistent subclinical infection and severe disease manifestations is a worthy goal of both veterinary and human medical scientists. Knowledge is being pursued by scientists in both veterinary and human medicine of the immunological mechanisms of clearance of the pathogens and resolution of the pathologic lesions, the host and ehrlichial pathogenic mechanisms mediating persistent infection, and the pathogenic mechanisms of the severe disease.

\section{History of Ehrlichioses and Anaplasmoses}

Ehrlichioses were the sole province of veterinary medicine until a case report of a man infected with an agent that was identified as an Ehrlichia by electron microscopy of circulating monocytes containing intravacuolar bacteria with the characteristic ultrastructural appearance of Ehrlichia 
accompanied by the development of antibodies reactive with Ehrlichia canis [1]. The actual pathogen, E. chaffeensis, was cultivated in 1991 and demonstrated to possess antigens shared with E. canis [2].

The history of veterinary discoveries of ehrlichioses long preceded these events. Theiler [3] identified a related pathogen in the family Anaplasmataceae, Anaplasma marginale, in 1910. Cowdry [4] identified the etiologic agent of heartwater in 1925, and Donatien and Lestoquard [5] determined that E. canis is the causative pathogen of canine monocytic ehrlichiosis in 1935. All of these discoveries were made in Africa. In 1940 Gordon et al. [6] identified Anaplasma phagocytophilum as the agent of tick-borne fever in the United Kingdom, and Ewing et al. [7] identified the agent of canine granulocytic ehrlichiosis that now bears his name, E. ewingii, in Oklahoma in 1971. These organisms were known through the years by several different names until molecular phylogeny sorted out their true genetic relationships in 1999 [8].

Additional human ehrlichioses have subsequently been discovered. In a private practice, infectious diseases subspecialist in Duluth, Minnesota, Johan Bakken, observed a disease in several of his patients who had cytoplasmic inclusions in some of their circulating neutrophils [9]. He suspected that these were ehrlichiae on the basis of their similarity to a photomicrograph in an update to the ehrlichiosis chapter in Mandell's textbook on infectious diseases that had recently arrived in the mail. Because Walker was the author of the update, Bakken sent blood smears, sera, and blood from patients, and paraffin blocks from an autopsy to his laboratory at the University of Texas Medical Branch at Galveston where J. Stephen Dumler led their study. After exhaustively determining that the patients did not have E. chaffeensis infection, a novel technique developed by Relman [10] was applied to DNA extracted from the patients' blood, namely polymerase chain reaction with universal primers for the eubacterial rrs gene. Laborious manual sequencing by Chen et al. [11] identified the agent as what was then known as E. phagocytophila [11]. Dumler was continuously involved in the project after completion of his fellowship and returning to the School of Medicine of the University of Maryland as a member of the faculty, contributing serological data and ultrastructural detection of the agent in autopsy tissue. The organism was cultivated by Goodman et al. [12] in 1996 and renamed A. phagocytophilum by Dumler et al. [8] in 1999. Subsequently, two additional human ehrlichioses and one additional human anaplasmosis have been discovered. Human infections with E. ewingii were identified in Missouri in 1999, and E. muris infections of patients in Minnesota and Wisconsin were discovered by Pritt et al. [13] in 2009 [14]. Human infections with a novel Anaplasma, A. capra, were discovered in China in 2015 [15].

\section{The Agents of Ehrlichioses}

Among the five genera in the family Anaplasmataceae of the order Rickettsiales, namely Anaplasma, Ehrlichia, Neorickettsia, Neoehrlichia, and Wolbachia, this article focuses on the diseases caused by organisms of the genus Ehrlichia.

Ehrlichiae undergo a developmental cycle with two physiologic forms: an infectious, nonreplicating, smaller $(0.4-0.6 \mu \mathrm{m})$ dense-core form with ribosomes and DNA condensed in the center of the bacterium, and a larger $(0.4-0.6 \mu \mathrm{m} \times 0.7-1.9 \mu \mathrm{m})$ noninfectious reticulate cell form that replicates by binary fission in a cytoplasmic vacuole [16-18]. The cytoplasmic vacuole containing a microcolony of ehrlichiae is the structure that is detected in circulating leukocytes by Romanovsky staining and has been called a morula (Latin for mulberry) because of its resemblance to that fruit. The cell wall of Ehrlichia lacks the structural components that are immunological pattern recognition molecules, lipopolysaccharide and peptidoglycan, a hint of the ehrlichial stealth infection strategy. The ehrlichial cell wall contains several proteins that have tandem repeat units which perform various functions, including adhesion to the host cell membrane, binding of host cytoplasmic proteins after secretion by a type I secretion system, and translocation to the host cell nucleus where they bind to DNA to stimulate and inhibit transcription of host cell genes with effects that favor ehrlichial survival. Ehrlichiae also have a $200 \mathrm{kDa}$ protein, which resembles host cell ankyrin, that is also translocated to the host cell nucleus and binds host cell chromatin. In addition, the ehrlichial cell wall also contains one or more of the family of $28 \mathrm{kDa}$ proteins that are encoded by a locus in the 
circular 1.2-1.5 $\times 10^{6}$ bp genome [19-22]. The $28 \mathrm{kDa}$ protein that is expressed appears to be related to adaptation to different hosts, e.g., p28-19 of E. chaffeensis is expressed in mammalian hosts, and p28-14 is expressed in the tick host [23]. The p28 locus in different species of Ehrlichia varies in size and number of p28 genes, often more than 20 genes. The 22 p2 $8 \mathrm{kDa}$ proteins of $E$. chaffeensis contain three hydrophilic, surface-exposed hypervariable domains. The small genomes, a result of reductive evolution, contain more than 400 conserved housekeeping genes and more than 300 hypothetical genes whose functions are unknown but likely are critical for the obligately intracellular lifestyle.

\section{Clinical Manifestations}

\subsection{Human Ehrlichioses}

Initially, human monocytotropic ehrlichiosis presents as an undifferentiated febrile illness with fever, headache, myalgia, and malaise [24]. Manifestations of multisystem disease such as nausea, vomiting, diarrhea, abdominal tenderness, regional lymphadenopathy, cough, rash, stiff neck, photophobia, and confusion occur in $20 \%-40 \%$ of patients. Meningoencephalitis occurs in $20 \%$, and acute respiratory distress syndrome occurs in the most severe cases. Hospitalization is required in $40 \%-60 \%$ of cases, and $2 \%$ of cases are fatal $[24,25]$. Characteristic laboratory abnormalities are leukopenia with both lymphocytopenia and neutropenia, thrombocytopenia, and elevated serum concentrations of hepatic transaminases. Pathologic lesions include meningoencephalitis, interstitial pneumonia, multifocal hepatocellular death, bone marrow containing granulomas likely reflecting clearance of the bacteria, erythrophagocytosis, myeloid hyperplasia, and megakaryocytosis, likely reflecting the mechanism of cytopenias and the compensatory responses to the cytopenias [26]. In immunocompetent persons even severe illness is associated with a paucity of organisms in the tissues, suggesting immunopathogenic mechanisms. In contrast, human monocytotropic ehrlichiosis in immunodeficient patients, such as persons with human immunodeficiency virus associated acquired immunodeficiency syndrome, is a severe illness with overwhelming quantities of ehrlichiae in the blood and organs [27].

Human infections with E. ewingii and E. muris have similar, although less severe, clinical presentations as human monocytotropic ehrlichiosis. No fatalities have been reported with either of these human ehrlichioses [14,27].

Febrile human illnesses associated with detection of antibodies reactive with E. chaffeensis have been observed in patients and the Perm region of Russia, where DNA sequences identical to those of E. muris were detected in Ixodes persulcatus ticks. This situation suggests the potential for a wider global distribution of human infections with E. muris [28].

\subsection{Canine Monocytic Ehrlichiosis}

Ehrlichia canis, E. chaffeensis, and E. ewingii infect dogs, but also have been reported to cause infection in humans. Canine monocytic ehrlichiosis caused by E. canis induces clinical and hematological changes that can be serious and even fatal. Vertebrate reservoirs of E. canis are limited to the family Canidae. Ehrlichia canis is transmitted by the brown dog tick, Rhipicephalus sanguineus, and the bacteria are maintained through the tick life stages by transstadial, but not by transovarian, transmission $[8,29]$. In the tick, the microorganism spreads from the midgut to the hemocele and in hemocytes to the salivary gland, and infection of the host occurs through the tick's salivary secretions in the site of the vector feeding.

Usually there is a history of tick infestation that is associated with nonspecific clinical manifestations $[30,31]$. The course of the disease classically can be divided into three phases: acute, subclinical, and chronic. The acute phase occurs after an incubation period of 8-20 days and persists for 2-4 weeks, during which there is multiplication of the bacteria in mononuclear cells, and spread of ehrlichiae within the host $[32,33]$. Canine ehrlichiosis may occur as a multisystemic disease, with or without bleeding, such as petechiae and/or dermal ecchymosis. Lymphadenopathy and/or 
splenomegaly occurs in $20 \%-25 \%$ of cases. Ocular signs may include anterior uveitis, chorioretinitis, papilledema, retinal hemorrhage, perivascular inflammation, retinal detachment, and even blindness. Convulsions, stupor, ataxia, central or peripheral vestibular dysfunction, cerebellar dysfunction, anisocoria, tremor, and generalized or localized hyperesthesia are observed in some infected animals as a result of meningitis or cerebral hemorrhage. Dogs with ehrlichial infection can also present with hemarthrosis or deposition of immune complexes in joints [31,34-36]. Hematologic changes are associated with autoimmunity or coagulopathy, including anti-platelet antibodies, persistent thrombocytopenia with increased numbers of large regenerative platelets, variable mild leukopenia, non-regenerative anemia, and hemolysis. The acute clinical phase resolves spontaneously [30-33,37]. Immunocompetent animals can eliminate the agent, even without specific treatment, or remain persistently infected reservoirs of the pathogen [37,38]. These animals enter the subclinical phase during which they appear healthy. Subsequently, these animals may develop pancytopenia associated with hypoplastic bone marrow failure leading to death.

\subsection{Canine Granulocytic Ehrlichiosis}

The primary vector of E. ewingii is A. americanum, the lone star tick [39]. The natural host is white-tailed deer, which can harbor infectious organisms, and the dog is another possible reservoir [40-42]. Dogs inoculated experimentally with E. ewingii develop fever, thrombocytopenia, and leukopenia. Bacteria are detected in blood around 10 days post infection, morulae are detected in neutrophils around 20 days post infection, and seroconversion occurs between 7 and 21 days, depending on the route of infection [43]. Dogs infected via tick-transmission develop detectable E. ewingii DNA in the blood between days 11 and 28. The infection dynamics of E. ewingii in dogs varies greatly based on the dose of inoculum and previous infection status. Dogs previously infected with E. ewingii may develop active infection upon challenge. Unlike dogs infected with E. ewingii for the first time, they do not develop fever or thrombocytopenia. Intermittent fever is common only among dogs during a primary infection with E. ewingii and in naturally infected dogs [44,45]. Less common presentations such as lameness, neutrophilic polyarthritis, anemia, peripheral edema, and lymphadenopathy may also occur in naturally infected dogs. Numerous hematologic and biochemical abnormalities have been associated with natural infections of E. ewingii in dogs and humans, including thrombocytopenia, leukopenia, high serum alkaline phosphatase concentration, high serum alanine aminotransferase, hypokalemia, hyperglobulinemia, hyperphosphatemia, hypophosphatemia, and hypocalcemia $[14,44,45]$. Thrombocytopenia may persist for several weeks.

\subsection{Heartwater}

The clinical disease caused by Ehrlichia (formerly Cowdria) ruminantium affects domestic and wild ruminants in many African countries and on Caribbean islands, and often causes death of clinically affected ruminants [46].

Infected animals present a peracute, acute, subacute, or subclinical form. The peracute form is relatively rare. High fever, respiratory distress, terminal convulsions, and diarrhea may precede death during the peracute form. The acute form is most often observed and is characterized by fever, inappetence, depression, listlessness, moist cough, bronchial rales, cyanosis of mucous membranes, dyspnea, and CNS signs. The acute form of disease is typically fatal in less than 1 week from the onset of clinical signs. The subacute form of heartwater, which is rarely encountered, is characterized by prolonged fever, cough, and mild incoordination. Affected animals recover or die within 1-2 weeks after the onset of the subacute form of disease. A mild or subclinical form of heartwater is characterized by transient fever and may occur in partially immune cattle or sheep, or calves that are younger than 3 weeks old [47]. 


\subsection{Coinfections of Ehrlichia and Other Tick-Borne Organisms}

Coinfections of ehrlichiae and other tick-borne agents have rarely been reported. A patient in North Carolina developed fever, headache, myalgia, nonproductive cough, nausea, and vomiting followed by worsening symptoms and a rash three days later. Laboratory studies revealed leukopenia, thrombocytopenia, hyponatremia, and mildly elevated hepatic transaminases. He reported tick bite and crushing ticks removed from his dog. Immunofluorescence staining of a skin lesion identified spotted fever group rickettsiae. Immunofluorescence assay (IFA) antibody titers to E. chaffeensis increased four-fold, from 32 to 128 [48].

Because the most highly prevalent tick in North Carolina is Amblyomma americanum, which is host for R. amblyommii, R. parkeri, and E. chaffeensis, it is most likely that the patient was coinfected with E. chaffeensis and either R. amblyommii or R. parkeri. Half of the A. americanum ticks in North Carolina carry $R$. amblyommii, and indirect evidence strongly suggests that this species can cause subclinical infection and self-limited illness. Although R. parkeri is found in a high proportion of A. maculatum ticks, its presence in a smaller portion of the highly prevalent $A$. americanum ticks may also result in human infections.

Studies at Fort Chaffee, Arkansas revealed that a substantial portion of soldiers, during summer exercises seroconverted to spotted fever group rickettsiae. The majority of these seroconversions were asymptomatic. However, at an odds ratio greater than 2, soldiers that seroconverted had a greater incidence of headache, myalgia, rash, joint pain, fever, chills, dyspnea, and confusion than nonseroconverters [49]. The ticks to which the soldiers were exposed were nearly all A. americanum, a very high proportion of which carry R. amblyommii in Arkansas. Experimental infections of guinea pigs with $R$. amblyommii cause a high titer seroconversion without illness [50].

Ixodes scapularis, the tick vector of E. muris, also transmits Anaplasma phagocytophilum, Babesia microti, Borrelia burgdorferi, and Powassan virus. Although coinfections of E. muris and these other agents have not been reported, there is a possibility of their occurrence. Coinfection does not have to result from transmission by a single dually infected tick because tick-exposed persons may experience more than one tick bite.

\section{Pathogenesis of Host-Ehrlichia Interactions}

\subsection{Human Monocytotropic Ehrlichiosis}

Apparently the vertebrate host-Ehrlichia interaction for a particular species of Ehrlichia is determined mainly by the host. For example, E. chaffeensis does not seem to cause significant disease in its natural host, although variable fever on days 17-21 post-inoculation has been observed in experimentally infected deer [51]. Paradoxically, severe disease occurs in some patients in association with a strong, possibly excessive, immune response, and fatalities also occur in severely immunocompromised persons. Severe disease in immunocompetent patients is associated with a paucity of organisms in the tissues, presumably as a result of an excessive immune response. On the other hand, severely immunocompromised patients' tissues contain large quantities of ehrlichiae.

A study comparing the host responses of a patient who suffered fatal human monocytotropic ehrlichiosis and a patient with mild E. chaffeensis infection revealed results similar to those of animal models of ehrlichiosis [52]. The fatal case was characterized by anemia, thrombocytopenia, and severe leukopenia and lymphopenia, increased serum hepatic transaminases, respiratory distress with hypoxia, seizure-like activity, multiorgan failure, and septic shock. The mild case had a three-day history of fever, myalgias, and headache that resolved with doxycycline therapy. The fatal case was associated with dysregulated cytokine and chemokine production with markedly higher concentrations of proinflammatory cytokines (tumor necrosis factor $\alpha$ (TNF- $\alpha$ ), interferon- $\gamma$ (IFN- $\gamma$ ), interleukin- $1 \alpha$ (IL-1 $\alpha)$, IL-1 $\beta$, and IL-6) and chemokines (monocyte chemoattractant protein-1 (MCP-1), macrophage inflammatory protein-1 $\alpha$ (MIP-1 $\alpha)$, and MIP-1 $\beta)$ that may have contributed to the multiorgan failure. The fatal case also had markedly increased levels of anti-inflammatory cytokines (IL-10 and IL-13) that 
may have caused the weak T helper 1 (Th1) cell-mediated immunity (low observed concentrations of IFN- $\gamma$ and IL-2 and severe lymphopenia). The fatal disease was also associated with greatly increased IL-8 and granulocyte-colony stimulating factor (G-CSF), possibly compensatory responses to the neutropenia.

\subsection{Canine Monocytic Ehrlichiosis}

After 7-12 days of E. canis infection ehrlichial morulae are detected in peripheral blood. Mononuclear cells in lymphoid organs release the dense-core ehrlichiae by exocytosis or lysis to infect other cells. Multiplication occurs primarily in macrophages and lymphocytes, resulting in lymphoreticular hyperplasia, and may result in enlargement of spleen, liver, and lymph nodes. Infected cells interact with the endothelial cells of the smaller blood vessels, causing vasculitis, and perivascular migration of macrophages and lymphocytes [53].

An antibody response is observed 13 days after infection [30,54,55], with a peak at $56-70$ days [55,56]. Humoral immunity by itself is insufficient to extinguish infection by E. canis [57]. Most infected dogs survive the acute phase. Animals treated with antibiotics or those untreated may evolve into an asymptomatic phase and maintain a persistent infection [58-60].

In canine ehrlichiosis, the persistence of the ehrlichial agent in the face of high titers of antibodies $[37,61]$ demonstrate that, for effective clearance of the microorganism, the cellular immune response of the host is required [62]. The maintenance of high titers of circulating antibodies against E. canis reflects persistent antigenic stimulation $[37,58]$. Another feature of the humoral response in ehrlichial infections is plasmocytosis in most affected organs, including bone marrow [63,64].

Genetic susceptibility or resistance of different canine breeds and the mode of transmission can affect the course of the infection. Some studies suggest that the disease is mediated by the immune response more than by the direct effects of the bacteria [65-67].

The concentrations of total proteins, total globulin, $\alpha-2$ globulin, $\beta-2$ globulin and $\gamma$-globulin are substantially elevated in infected dogs, and the albumin/globulin ratio is low in infected dogs. Polyclonal gammopathy is reflected in hypergammaglobulinemia $[66,68]$.

Neutropenia in infected dogs suggests that these animals are immunocompromised and, therefore, more susceptible to secondary infections that can result in an unfavorable outcome [68]. The high anti-E. canis antibody concentration detected in asymptomatic dogs for months after the acute phase of infection, as well as an absolute lymphocytosis and polyclonal gammopathy, indicate a prolonged duration of infection and chronic antigenic stimulation, reflecting the inability of some animals to naturally eliminate the infection after the acute phase of the disease $[37,69,70]$.

Thrombocytopenia and thrombocytopathy observed in ehrlichiosis involve immunological and inflammatory mechanisms related to increased consumption and decreased half-life of platelets, likely due to splenic sequestration. IgG antibodies directed against platelet proteins can lead to reduction in the number of platelets. The serum level of a particular cytokine, platelet migration inhibition factor, is inversely proportional to the platelet count with elevations associated with more virulent strains.

Ehrlichiae targeting the innate immune system activate the production of IL-12 by antigen-presenting cells, inducing the development of a Th1 response and IFN- $\gamma$ secretion by CD4 $\mathrm{T}$ cells, which plays a role in host control of ehrlichial infection. Lymphoid organs such as spleen and lymph nodes of dogs experimentally infected with E. canis contain cells with reduced expression of molecules of major histocompatibility complex class II (MHC II) [63]. In ehrlichial infections, there is an inverted $\mathrm{CD} 4: \mathrm{CD} 8$ ratio of $\mathrm{T}$ lymphocytes in peripheral blood; more specifically, there is a reduction in levels of CD4+ T cells [55,71].

Investigation of the expression of mRNA of cytokines in dogs experimentally infected by E. canis demonstrates persistent expression of TNF- $\alpha$ and IFN- $\gamma$ mRNA, and low levels of mRNA of IL- $1 \beta$, IL-2, IL-4, and IL-6 throughout 56 days of infection [72]. In clinically moderate ehrlichiosis there is persistent elevation of IL- $1 \beta$ and IL-8, and in dogs with severe acute ehrlichiosis there are reduced levels of IFN- $\gamma$ and TNF- $\alpha$ [73]. 
In splenectomized dogs, the clinical and hematological changes are mild compared to intact animals. Significant differences observed between splenectomized and intact dogs can be explained by the mechanisms involved in the pathogenesis of canine ehrlichiosis involving erythrophagocytosis, leukophagocytosis, and thrombocytophagocytosis [74]. The spleen is probably the last organ to maintain E. canis infection during recovery, possibly in splenic macrophages, avoiding immune clearance [37].

\subsection{Canine Granulocytic Ehrlichiosis}

Very little is known about E. ewingii and the pathogenesis of canine granulocytic ehrlichiosis. Neutrophils taken from a dog naturally infected with $E$. ewingii have been maintained for various periods in cell culture, but continuous productive replication has not been achieved. The percentage of apoptotic neutrophils in infected dogs is significantly lower than in uninfected dogs after culture, suggesting that neutrophil apoptosis is delayed by E. ewingii infection allowing further ehrlichial growth. Ehrlichia ewingii infection delays the loss of mitochondrial membrane potential associated with spontaneous apoptosis in neutrophils [75].

\subsection{Heartwater}

Once inoculated into the host, E. ruminantium typically resides inside intracytoplasmic inclusions in neutrophils and endothelial cells [76,77]. Different strains of E. ruminantium often fail to induce heterologous cross-protection, apparently because of antigenic diversity [76]. Genetic diversity also impacts the degree of pathogenicity of various strains of E. ruminantium. Some strains are highly virulent; others appear to be nonpathogenic [78,79].

Amblyomma spp. ticks transmit $E$. ruminantium to susceptible ruminant hosts. In Africa, there are five native tick species, $A$. variegatum, A. hebraeum, A. lepidum, A. astrion, and A. pomposum that are considered natural vectors of heartwater. Introduction of cattle infested with $A$. variegatum led to the presence of heartwater on Caribbean islands. Domestic cattle, sheep, and goats are target species for heartwater, as well as other less familiar domestic ruminants.

The tick cycle of the ehrlichial infection begins in the intestinal epithelial cells and spreads via the hemolymph to the tick salivary glands. E. ruminantium can be transmitted transstadially, but rarely, if ever, transovarially $[80,81]$. Only a portion of infected ticks transmit E. ruminantium during feeding, and transmission requires $2-3$ days ( $38 \mathrm{~h}$ ) for nymphs and up to 4 days for adult ticks [80,81].

E. ruminantium organisms delivered by infective tick challenge are more virulent than organisms delivered as needle challenge with infected blood $[82,83]$.

Vertical transmission occurs from cows to neonatal calves by ingestion of E. ruminantium-infected leukocytes in colostrum [84]. Subcutaneous, intramuscular, and intraperitoneal inoculation of infective blood into susceptible animals can also initiate infection [80].

Initial replication takes place in cells of the mononuclear phagocytic system in the regional lymph nodes, and dissemination occurs via the blood stream with invasion of vascular endothelial cells. Antibodies do not seem to control the course of the disease.

After transmission the organisms reside in regional lymph nodes where replication occurs [85]. The febrile stage develops between 3 and 10 days after transmission, at which time organisms are located in plasma cells, neutrophils and, occasionally, other granulocytes [86,87].

Genetic factors are important for the development of immunity against heartwater. Immunity is probably maintained best in sheep; in contrast, immunity is of the shortest duration in cattle [86]. Calves, kids, and lambs have natural resistance against heartwater during the neonatal period, and resistance appears to be unrelated to the immune status of the respective dam $[86,88]$. Following recovery from clinical disease, some domestic ruminants can become reinfected with E. ruminantium, resulting in another bout of clinical disease or even death [47]. In addition, some animals may develop a transient carrier state. The mortality rate in clinically affected animals also 
varies considerably and is particularly dependent on when treatment is started during the course of the disease. Mortality rates vary between $5 \%$ and $10 \%$ [89].

The tropism of E. ruminantium for endothelial cells results in damage to capillaries. The resulting increased capillary permeability is particularly detrimental to cardiac and respiratory function. Primary clinicopathologic changes include progressive anemia, fluctuations in total and differential leukocyte counts (i.e., neutropenia, eosinopenia, and lymphocytosis), hyperbilirubinemia, hypoalbuminemia, decreased concentrations of total serum proteins, and azotemia.

Infection of mice was the earliest method used to demonstrate variability between strains, and three different levels of pathogenicity are recorded: pathogenic genotypes which can kill mice, genotypes which infect mice but are not pathogenic, and non-infective genotypes. The closely related Panola Mountain Ehrlichia in the U.S. causes a mild febrile illness in goats and in humans [90,91], and its natural reservoir may be the widely distributed white-tailed deer [92]. Panola Mountain Ehrlichia has been found in A. americanum ticks, but does not appear to represent a heartwater threat [93].

There are important antigenic variants of E. ruminantium. For the purpose of vaccine development, it is important to find genotypes which can confer cross-immunity to as wide a range of strains as possible. The Welgevonden genotype is the only one which stimulates complete cross-protection against challenge with any of the other strains.

Dogs with clinical manifestations suggesting canine ehrlichiosis had detectable E. ruminantium, suggesting that an E. ruminantium variant contributed to these animals' illness [94]. Recently E. ruminantium DNA has also been detected in three human serum samples using the pCS20 assay. All three individuals died, and other E. ruminantium-specific gene sequences were also found in the samples, suggesting that at least some E. ruminantium variants can cause a lethal infection in humans [95].

\section{Mouse Models of Ehrlichioses}

While studies of ehrlichial infections in the natural hosts, such as E. canis in dogs and E. ruminantium in domestic ruminants, have defined the disease in terms of the pathologic lesions and pathophysiology as determined by the concentrations of biochemical analytes and cellular responses in blood, mechanistic studies of immunity and pathogenesis are most challenging in these outbred hosts. Descriptive studies, although essential, fail to determine the pathogenic and immune mechanisms. Such research is enabled by (1) the existence of susceptible and resistant inbred strains of animals that permit studies such as adoptive transfer of genetically compatible immune cell populations and (2) the availability of gene knockout animals lacking a specific gene or genes. Mice are the species in which such inbred susceptible, resistant, and gene knockout strains have been extensively developed.

Of course, mice differ considerably from domestic ruminants, dogs, and humans. Yet they have been used most extensively to investigate ehrlichial immunity and pathogenesis. The challenge lies in interpreting the data from experiments in mice and applying the knowledge to veterinary and human clinical diseases.

Among the mice that have been used to study ehrlichial immunity, immunopathology, and pathogenesis are $\mathrm{C} 57 \mathrm{BL} / 6, \mathrm{C} 3 \mathrm{H} / \mathrm{HeN}, \mathrm{C} 3 \mathrm{H} / \mathrm{HeJ}, \mathrm{AKR}, \mathrm{BALB} / \mathrm{c}, \mathrm{C} . \mathrm{B} 17, \mathrm{SCID}$, and knockout mice for genes CD4, CD8, MHC II, TAP, $\beta_{2} \mathrm{~m}$, perforin, TNF receptor, IL-12, IL-21, and IL-18 receptors, TLR4, TLR9, TLR2, Rag, IFN- $\gamma$ receptor, IFN- $\gamma$, IFN- $\alpha$, TNF- $\alpha$, lymphotoxin $\alpha$, B cells ( $\mu$ MT), secretory IgM, class switching, and MyD88 [96-117]. These strains of mice have been utilized for studies of infections with species of Ehrlichia that cause subclinical self-limited infections, e.g., E. chaffeensis in C57BL/ 6 mice; mild-to-subclinical infections with lifelong persistence, e.g., E. muris in C57BL/ 6 mice; and severe, even uniformly, fatal infections, e.g., an unnamed Ehrlichia species obtained from Japanese Ixodes ovatus ticks (IOE). The route of inoculation affects the severity and outcome of infection, e.g., intraperitoneal infection with IOE is fatal except with the very lowest dose of Ehrlichia, and intradermal infection with IOE is sublethal except with the highest doses [118]. Infection of mice with the E. muris strain from the upper Midwestern United States illustrates these principles well. Intraperitoneal and 
intravenous inoculation with this E. muris strain causes dose-dependent lethality (higher dose) or sublethal persistent (lower dose) infection [119]. For as yet-to-be-determined reasons, mice that survive intravenous infection succumb to subsequent intravenous challenge, while mice surviving intradermal infection are immune to the same intravenous challenge dose. This strain is the only Ehrlichia that is pathogenic for humans for which a mouse model of ehrlichial acquisition by feeding of the natural vector, I. scapularis, on infected mice and transmission by infected ticks during feeding to uninfected mice has been developed [120]. In contrast with the intradermal needle inoculation that results in sublethal infection, tick transmission causes $27 \%$ lethality. The mechanisms mediating this enhanced severity of cutaneous inoculation by ticks are as yet undetermined.

A mouse model that has played an important role in dissecting the mechanisms of immunity to lethal ehrlichial infection is challenge of mice that have been persistently infected with E. muris for 30 days or more with an ordinarily lethal dose of IOE [121]. These mice survive with strong Ehrlichia-specific secondary IFN- $\gamma$ producing effector/effector memory CD4 and CD8 T cell responses, enhanced secondary anti-ehrlichial antibody response, accelerated bacterial clearance, and formation of granulomas.

\section{Mechanisms of Pathogenesis and Immunity Determined in Experimental Mouse Studies}

There are differences in some of the ehrlichial genes expressed in the tick and vertebrate hosts [122]. Expression of a greater number of genes occurs in ticks, and the course of infection in vertebrate hosts differs according to whether the source of ehrlichiae inoculated originated from infected tick cells or infected vertebrate cells in terms of the duration of infection and the humoral immune response [51,107,122].

Antibodies play an important role as a host defense against ehrlichiae. Mice lacking mature B cells that do not produce IgM or IgG, mice lacking Fc $\gamma$ receptor I or complement receptors 1 and 2, or mice depleted of C3 die after inoculation with an ordinarily sublethal dose of IOE [123]. Although E. muris-primed wild type mice and mice genetically deficient in CD4 T cells, CD8 T cells, MHC class II, IL-12, IFN- $\gamma$, or TNF- $\alpha$ survive challenge with an ordinarily lethal dose of IOE, B cell-deficient mice succumb to the infection, indicating an important role for antibodies as a host defense in this model [108].

CD4 and CD8 T lymphocytes also contribute to immune control of ehrlichial infection. Although E. muris causes sublethal infection in wild type $\mathrm{C} 3 \mathrm{H} / \mathrm{HeN}$ mice, $81 \%$ of mice genetically deficient in MHC class I, 44\% of CD4 T cell-depleted mice, and 80\% of mice depleted of both CD4 and CD8 T cells die when infected with the same dose of E. muris [103]. Ordinarily, E. chaffeensis infection of mice is of short duration, but clearance is delayed in CD4 T cell knockout mice, and persistent infection occurs in MHC class II knockout mice [101,104]. A hint that CD8 T cells contribute to the pathogenesis of severe ehrlichiosis is the observation that $57 \%$ of CD8 T cell knockout mice survive, and the duration of survival is longer after infection with an ordinarily lethal inoculum of E. ruminantium [98]. The lethal IOE mouse model is characterized by overproduction of TNF- $\alpha$ by CD8 T cells, downregulation of IFN- $\gamma$ production by CD4 T cells, low IL-12 in the spleen, and systemic overproduction of IL-10 [121]. Mice lacking a gene crucial for CD8 $\mathrm{T}$ cell function, $\beta_{2}$ microglobulin, are highly resistant, and gene knockout mice for TAP (transporter associated with antigen processing) are substantially resistant to an ordinarily lethal dose of IOE in association with markedly lower TNF- $\alpha$ and IL-10 production, and restored CD4 T cell quantities including those producing IFN- $\gamma$. These data are consistent with CD8 $\mathrm{T}$ cells playing a role in excess production of TNF- $\alpha$ and IL-10 and the immune elimination of CD4 T cells [106]. Depletion of IL-10 restores the population of CD4 T cells in infected mice, indicating a role of this cytokine in the CD4 T cell depletion. A significant portion of the major histopathologic damage, hepatic injury, as well as control of bacterial infection is mediated by perforin. The pathogenic importance of TNF- $\alpha$ in IOE-induced liver injury is demonstrated by the greater resistance of mice deficient in both TNF receptors I and II (p55 and p75) [105]. TNF- $\alpha$ neutralization fails to increase resistance to IOE but may be less effective in blocking apoptotic signaling of the cell membrane form 
of TNF- $\alpha$ through TNF receptor p75. Infection of TNF receptor knockout and TNF- $\alpha$ neutralized mice results in a higher bacterial burden. Clearly, TNF- $\alpha$ plays both pathogenic and protective roles in IOE infection of mice.

IL-18, which is highly expressed in the liver of mice during a lethal IOE infection, also contributes to the immunopathogenesis of fatal IOE infection. IL-18 receptor knockout mice have less host cell apoptosis, reduced hepatic inflammation, enhanced bacterial clearance, and prolonged survival compared with wild-type mice infected with IOE. Treatment of wild-type mice infected with mildly virulent $E$. muris with recombinant IL-18 increases hepatic injury and reduces bacterial clearance [115].

A contribution of natural killer (NK) cells to protective immunity against ehrlichiosis was demonstrated by the deaths of $80 \%$ of NK cell-depleted, E. muris-primed mice challenged with IOE [117]. In conclusion, various components of the immune system contribute to the pathogenesis of the disease process as well as to control of the infection. Three divergent immune-mediated outcomes of infection with different ehrlichial organisms are immune-mediated lethality associated with reduction in bacterial loads, subclinical persistence of infection, and transient sublethal infection.

Common clinical manifestations of ehrlichioses are thrombocytopenia, leukopenia, and anemia. Although there is evidence for mononuclear phagocytes removal of these elements, there are also investigations of the effects of ehrlichial infections of mice on the hematopoietic stem cells, hematopoietic progenitor cells, and myelopoiesis and the effects of innate and adaptive immunity on hemopoietic activity [109-111,124].

\section{Prospects for Development of Vaccines}

Vaccination ideally primes the immune system to develop memory cells that confront the invasive pathogen early in the incubation period to prevent the organism's growth, dissemination, and disease mediation. Passive transfer of antibodies and adoptive transfer of immune cells of a specific subset can provide the host with individual immune components to evaluate their contribution to protective immunity that might be provided by vaccination. Passive transfer of not only polyclonal antibodies but also monoclonal antibodies, such as antibodies to the p28 expressed on E. chaffeensis, protect SCID mice against this agent $[100,103]$. Adoptive transfer of all three immune components stimulated by persistent E. muris - namely, polyclonal antibody and Ehrlichia-specific CD4 and CD8 T cells producing IFN- $\gamma$, each of which provides only partial protection individually-are required for strong protection against an ordinarily lethal IOE infection [121]. The role of E. muris-primed NK cells was demonstrated by protective immunity provided by their adoptive transfer into Rag2/interleukin-2 receptor knockout mice. These results suggest that an effective vaccine should stimulate the production of antibodies to specific proteins and memory CD4 and CD8 T cells and even memory-like NK cells that produce the appropriate cytokines including IFN- $\gamma$.

Much knowledge remains to be elucidated before rationally designed vaccines can be developed for human and veterinary ehrlichioses. A multi-passage attenuated strain of E. canis was experimentally tested as a vaccine against wild type bacteria, demonstrating protection in dogs [125]. Also, several vaccine trials have been performed for E. ruminantium [83,126]; however, immunization was not protective against $E$. ruminantium transmitted by natural tick challenge.

Because ehrlichiae are maintained in natural cycles for which no effective methods currently exist for control or eradication, vaccine development is the most compelling approach to ameliorate the effects of ehrlichiosis. A candid assessment is that greater attention to vaccine development is needed.

Acknowledgments: The authors wish to express their gratitude to Angela Culler for her expert secretarial contributions.

Author Contributions: The two authors contributed equally to this work.

Conflicts of Interest: The authors declare no conflict of interest. 


\section{References}

1. Maeda, K.; Markowitz, N.; Hawley, R.C.; Ristic, M.; Cox, D.; McDade, J.E. Human infection with Ehrlichia canis, a leukocytic rickettsia. N. Engl. J. Med. 1987, 316, 853-856. [CrossRef] [PubMed]

2. Anderson, B.E.; Dawson, J.E.; Jones, D.C.; Wilson, K.H. Ehrlichia chaffeensis, a new species associated with human ehrlichiosis. J. Clin. Microbiol. 1991, 29, 2838-2842. [PubMed]

3. Theiler, A. Anaplasma marginale (Gen. and Spec. nov.). The marginal points in the blood of cattle suffering from a specific disease. Report of the Government Bacteriologist 1908-1909; Government Printer and Stationery Office: Pretoria, South Africa, 1910; pp. 7-64.

4. Cowdry, E.V. Studies on the etiology of heartwater: I. Observation of a rickettsia, rickettsia ruminantium (n. Sp.), in the tissues of infected animals. J. Exp. Med. 1925, 42, 231-252. [CrossRef]

5. Donatien, A.; Lestoquard, F. Existence en alge! Rie d'une rickettsia du chien. Bull. Soc. Pathol. Exot. 1935, 28, 418-419.

6. Gordon, W.S.; Brownlee, A.; Wilson, D.R. Studies in louping-ill, tick-borne fever and scrapie. In Proceedings of the 3rd International Congress of Microbiology, New York, NY, USA, 2-9 September 1939; pp. 362-363.

7. Ewing, S.A.; Roberson, W.R.; Buckner, R.G.; Hayat, C.S. A new strain of Ehrlichia canis. J. Am. Vet. Med. Assoc. 1971, 159, 1771-1774. [PubMed]

8. Dumler, J.S.; Barbet, A.F.; Bekker, C.P.; Dasch, G.A.; Palmer, G.H.; Ray, S.C.; Rikihisa, Y.; Rurangirwa, F.R. Reorganization of genera in the families rickettsiaceae and anaplasmataceae in the order rickettsiales: Unification of some species of Ehrlichia with anaplasma, cowdria with Ehrlichia and Ehrlichia with neorickettsia, descriptions of six new species combinations and designation of Ehrlichia equi and "hge agent" as subjective synonyms of Ehrlichia phagocytophila. Int. J. Syst. Evol. Microbiol. 2001, 51, 2145-2165. [PubMed]

9. Bakken, J.S.; Dumler, J.S.; Chen, S.M.; Eckman, M.R.; Van Etta, L.L.; Walker, D.H. Human granulocytic ehrlichiosis in the upper midwest United States. A new species emerging? JAMA 1994, 272, 212-218. [CrossRef] [PubMed]

10. Relman, D.A.; Loutit, J.S.; Schmidt, T.M.; Falkow, S.; Tompkins, L.S. The agent of bacillary angiomatosis. An approach to the identification of uncultured pathogens. N. Engl. J. Med. 1990, 323, 1573-1580. [CrossRef] [PubMed]

11. Chen, S.M.; Dumler, J.S.; Bakken, J.S.; Walker, D.H. Identification of a granulocytotropic Ehrlichia species as the etiologic agent of human disease. J. Clin. Microbiol. 1994, 32, 589-595. [PubMed]

12. Goodman, J.L.; Nelson, C.; Vitale, B.; Madigan, J.E.; Dumler, J.S.; Kurtti, T.J.; Munderloh, U.G. Direct cultivation of the causative agent of human granulocytic ehrlichiosis. N. Engl. J. Med. 1996, 334, 209-215. [CrossRef] [PubMed]

13. Pritt, B.S.; Sloan, L.M.; Johnson, D.K.; Munderloh, U.G.; Paskewitz, S.M.; McElroy, K.M.; McFadden, J.D.; Binnicker, M.J.; Neitzel, D.F.; Liu, G.; et al. Emergence of a new pathogenic Ehrlichia species, wisconsin and minnesota, 2009. N. Engl. J. Med. 2011, 365, 422-429. [CrossRef] [PubMed]

14. Buller, R.S.; Arens, M.; Hmiel, S.P.; Paddock, C.D.; Sumner, J.W.; Rikhisa, Y.; Unver, A.; Gaudreault-Keener, M.; Manian, F.A.; Liddell, A.M.; et al. Ehrlichia ewingii, a newly recognized agent of human ehrlichiosis. N. Engl. J. Med. 1999, 341, 148-155. [CrossRef] [PubMed]

15. Li, H.; Zheng, Y.C.; Ma, L.; Jia, N.; Jiang, B.G.; Jiang, R.R.; Huo, Q.B.; Wang, Y.W.; Liu, H.B.; Chu, Y.L.; et al. Human infection with a novel tick-borne anaplasma species in China: A surveillance study. Lancet Infect. Dis. 2015, 15, 663-670. [CrossRef]

16. Zhang, J.Z.; Popov, V.L.; Gao, S.; Walker, D.H.; Yu, X.J. The developmental cycle of Ehrlichia chaffeensis in vertebrate cells. Cell. Microbiol. 2007, 9, 610-618. [CrossRef] [PubMed]

17. Popov, V.L.; Chen, S.M.; Feng, H.M.; Walker, D.H. Ultrastructural variation of cultured Ehrlichia chaffeensis. J. Med. Microbiol. 1995, 43, 411-421. [CrossRef] [PubMed]

18. Popov, V.L.; Korenberg, E.I.; Nefedova, V.V.; Han, V.C.; Wen, J.W.; Kovalevskii, Y.V.; Gorelova, N.B.; Walker, D.H. Ultrastructural evidence of the ehrlichial developmental cycle in naturally infected ixodes persulcatus ticks in the course of coinfection with rickettsia, borrelia, and a flavivirus. Vector Borne Zoonotic Dis. 2007, 7, 699-716. [CrossRef] [PubMed]

19. Yu, X.; McBride, J.W.; Zhang, X.; Walker, D.H. Characterization of the complete transcriptionally active Ehrlichia chaffeensis $28 \mathrm{kda}$ outer membrane protein multigene family. Gene 2000, 248, 59-68. [CrossRef] 
20. Yu, X.J.; Walker, D.H. Sequence and characterization of an Ehrlichia chaffeensis gene encoding 314 amino acids highly homologous to the nad a enzyme. FEMS Microbiol. Lett. 1997, 154, 53-58. [CrossRef] [PubMed]

21. McBride, J.W.; Comer, J.E.; Walker, D.H. Novel immunoreactive glycoprotein orthologs of Ehrlichia spp. Ann. N. Y. Acad. Sci. 2003, 990, 678-684. [CrossRef] [PubMed]

22. Dunning Hotopp, J.C.; Lin, M.; Madupu, R.; Crabtree, J.; Angiuoli, S.V.; Eisen, J.A.; Eisen, J.; Seshadri, R.; Ren, Q.; Wu, M.; et al. Comparative genomics of emerging human ehrlichiosis agents. PLoS Genet. 2006, 2, e21.

23. Singu, V.; Liu, H.; Cheng, C.; Ganta, R.R. Ehrlichia chaffeensis expresses macrophage- and tick cell-specific 28-kilodalton outer membrane proteins. Infect. Immun. 2005, 73, 79-87. [CrossRef] [PubMed]

24. Fishbein, D.B.; Dawson, J.E.; Robinson, L.E. Human ehrlichiosis in the United States, 1985 to 1990. Ann. Intern. Med. 1994, 120, 736-743. [CrossRef] [PubMed]

25. Olano, J.P.; Masters, E.; Hogrefe, W.; Walker, D.H. Human monocytotropic ehrlichiosis, Missouri. Emerg. Infect. Dis. 2003, 9, 1579-1586. [CrossRef] [PubMed]

26. Dumler, J.S.; Dawson, J.E.; Walker, D.H. Human ehrlichiosis: Hematopathology and immunohistologic detection of Ehrlichia chaffeensis. Hum. Pathol. 1993, 24, 391-396. [CrossRef]

27. Paddock, C.D.; Folk, S.M.; Shore, G.M.; Machado, L.J.; Huycke, M.M.; Slater, L.N.; Liddell, A.M.; Buller, R.S.; Storch, G.A.; Monson, T.P.; et al. Infections with Ehrlichia chaffeensis and Ehrlichia ewingii in persons coinfected with human immunodeficiency virus. Clin. Infect. Dis. 2001, 33, 1586-1594. [CrossRef] [PubMed]

28. Ravyn, M.D.; Korenberg, E.I.; Oeding, J.A.; Kovalevskii, Y.V.; Johnson, R.C. Monocytic Ehrlichia in ixodes persulcatus ticks from Perm, Russia. Lancet 1999, 353, 722-723. [CrossRef]

29. Groves, M.G.; Dennis, G.L.; Amyx, H.L.; Huxsoll, D.L. Transmission of Ehrlichia canis to dogs by ticks (Rhipicephalus sanguineus). Am. J. Vet. Res. 1975, 36, 937-940. [PubMed]

30. Keysary, A.; Waner, T.; Rosner, M.; Warner, C.K.; Dawson, J.E.; Zass, R.; Biggie, K.L.; Harrus, S. The first isolation, in vitro propagation, and genetic characterization of Ehrlichia canis in Israel. Vet. Parasitol. 1996, 62, 331-340. [CrossRef]

31. Cohn, L.A. Ehrlichiosis and related infections. Vet. Clin. N. Am. Small Anim. Pract. 2003, 33, 863-884. [CrossRef]

32. Immelman, A.; Button, C. Ehrlichia canis infection (tropical canine pancytopaenia or canine rickettsiosis). J. S. Afr. Vet. Assoc. 1973, 44, 241-245. [PubMed]

33. Woody, B.J.; Hoskins, J.D. Ehrlichial diseases of dogs. Vet. Clin. N. Am. Small Anim. Pract. 1991, $21,75-98$. [CrossRef]

34. Codner, E.C.; Caceci, T.; Saunders, G.K.; Smith, C.A.; Robertson, J.L.; Martin, R.A.; Troy, G.C. Investigation of glomerular lesions in dogs with acute experimentally induced Ehrlichia canis infection. Am. J. Vet. Res. 1992, 53, 2286-2291. [PubMed]

35. Codner, E.C.; Maslin, W.R. Investigation of renal protein loss in dogs with acute experimentally induced Ehrlichia canis infection. Am. J. Vet. Res. 1992, 53, 294-299. [PubMed]

36. Luckschander, N.; Kleiter, M.; Willmann, M. Renal amyloidosis caused by Ehrlichia canis. Schweiz Arch. Tierheilkd 2003, 145, 482-485. [CrossRef] [PubMed]

37. Harrus, S.; Waner, T.; Aizenberg, I.; Foley, J.E.; Poland, A.M.; Bark, H. Amplification of ehrlichial dna from dogs 34 months after infection with Ehrlichia canis. J. Clin. Microbiol. 1998, 36, 73-76. [PubMed]

38. Murphy, G.L.; Ewing, S.A.; Whitworth, L.C.; Fox, J.C.; Kocan, A.A. A molecular and serologic survey of Ehrlichia canis, e. Chaffeensis, and e. Ewingii in dogs and ticks from Oklahoma. Vet. Parasitol. 1998, 79, 325-339. [CrossRef]

39. Anziani, O.S.; Ewing, S.A.; Barker, R.W. Experimental transmission of a granulocytic form of the tribe ehrlichieae by dermacentor variabilis and amblyomma americanum to dogs. Am. J. Vet. Res. 1990, 51, 929-931. [PubMed]

40. Yabsley, M.J.; Varela, A.S.; Tate, C.M.; Dugan, V.G.; Stallknecht, D.E.; Little, S.E.; Davidson, W.R. Ehrlichia ewingii infection in white-tailed deer (Odocoileus virginianus). Emerg. Infect. Dis. 2002, 8, 668-671. [CrossRef] [PubMed]

41. Arens, M.Q.; Liddell, A.M.; Buening, G.; Gaudreault-Keener, M.; Sumner, J.W.; Comer, J.A.; Buller, R.S.; Storch, G.A. Detection of Ehrlichia spp. in the blood of wild white-tailed deer in missouri by PCR assay and serologic analysis. J. Clin. Microbiol. 2003, 41, 1263-1265. [CrossRef] [PubMed] 
42. Liddell, A.M.; Stockham, S.L.; Scott, M.A.; Sumner, J.W.; Paddock, C.D.; Gaudreault-Keener, M.; Arens, M.Q.; Storch, G.A. Predominance of Ehrlichia ewingii in Missouri dogs. J. Clin. Microbiol. 2003, 41, 4617-4622. [CrossRef] [PubMed]

43. Yabsley, M.J.; Adams, D.S.; O’Connor, T.P.; Chandrashekar, R.; Little, S.E. Experimental primary and secondary infections of domestic dogs with Ehrlichia ewingii. Vet. Microbiol. 2011, 150, 315-321. [CrossRef] [PubMed]

44. Goodman, R.A.; Hawkins, E.C.; Olby, N.J.; Grindem, C.B.; Hegarty, B.; Breitschwerdt, E.B. Molecular identification of Ehrlichia ewingii infection in dogs: 15 Cases (1997-2001). J. Am. Vet. Med. Assoc. 2003, 222, 1102-1107. [CrossRef] [PubMed]

45. Gieg, J.; Rikihisa, Y.; Wellman, M. Diagnosis of Ehrlichia ewingii infection by PCR in a puppy from Ohio. Vet. Clin. Pathol. 2009, 38, 406-410. [CrossRef] [PubMed]

46. Vachiéry, N.; Jeffery, H.; Pegram, R.; Aprelon, R.; Pinarello, V.; Kandassamy, R.L.; Raliniaina, M.; Molia, S.; Savage, H.; Alexander, R.; et al. Amblyomma variegatum ticks and heartwater on three caribbean islands. Ann. N. Y. Acad. Sci. 2008, 1149, 191-195.

47. Kasari, T.R.; Miller, R.S.; James, A.M.; Freier, J.E. Recognition of the threat of Ehrlichia ruminantium infection in domestic and wild ruminants in the continental United States. J. Am. Vet. Med. Assoc. 2010, 237, 520-530. [CrossRef] [PubMed]

48. Sexton, D.J.; Corey, G.R.; Carpenter, C.; Kong, L.Q.; Gandhi, T.; Breitschwerdt, E.; Hegarty, B.; Chen, S.M.; Feng, H.M.; Yu, X.J.; et al. Dual infection with Ehrlichia chaffeensis and a spotted fever group rickettsia: A case report. Emerg. Infect. Dis. 1998, 4, 311-316. [CrossRef] [PubMed]

49. McCall, C.L.; Curns, A.T.; Rotz, L.D.; Singleton, J.A.; Treadwell, T.A.; Comer, J.A.; Nicholson, W.L.; Olson, J.G.; Childs, J.E. Fort chaffee revisited: The epidemiology of tick-borne rickettsial and ehrlichial diseases at a natural focus. Vector Borne Zoonotic Dis. 2001, 1, 119-127. [CrossRef] [PubMed]

50. Blanton, L.S.; Mendell, N.L.; Walker, D.H.; Bouyer, D.H. "Rickettsia amblyommii" induces cross protection against lethal rocky mountain spotted fever in a guinea pig model. Vector Borne Zoonotic Dis. 2014, 14, 557-562. [CrossRef] [PubMed]

51. Nair, A.D.; Cheng, C.; Jaworski, D.C.; Willard, L.H.; Sanderson, M.W.; Ganta, R.R. Ehrlichia chaffeensis infection in the reservoir host (white-tailed deer) and in an incidental host (dog) is impacted by its prior growth in macrophage and tick cell environments. PLoS ONE 2014, 9, e109056. [CrossRef] [PubMed]

52. Ismail, N.; Walker, D.H.; Ghose, P.; Tang, Y.W. Immune mediators of protective and pathogenic immune responses in patients with mild and fatal human monocytotropic ehrlichiosis. BMC Immunol. 2012, 13, 26. [CrossRef] [PubMed]

53. Almosny, N. Hemoparasitoses em Pequenos Animais Domesticos e Como Zoonoses; Rio de Janeiro: Livros, Brazil, 2002; p. 135.

54. Gaunt, S.D.; Corstvet, R.E.; Berry, C.M.; Brennan, B. Isolation of Ehrlichia canis from dogs following subcutaneous inoculation. J. Clin. Microbiol. 1996, 34, 1429-1432. [PubMed]

55. Hasegawa, M.Y.; Kohayagawa, A.; Brandão, L.P.; Morgulis, M.S.; Hagiwara, M.K. Evaluation of neutrophil oxidative metabolism in canine monocytic ehrlichiosis. Vet. Clin. Pathol. 2005, 34, 213-217. [CrossRef] [PubMed]

56. Harrus, S.; Kass, P.H.; Klement, E.; Waner, T. Canine monocytic ehrlichiosis: A retrospective study of 100 cases, and an epidemiological investigation of prognostic indicators for the disease. Vet. Rec. 1997, 141, 360-363. [CrossRef] [PubMed]

57. Nyindo, M.; Huxsoll, D.L.; Ristic, M.; Kakoma, I.; Brown, J.L.; Carson, C.A.; Stephenson, E.H. Cell-mediated and humoral immune responses of german shepherd dogs and beagles to experimental infection with Ehrlichia canis. Am. J. Vet. Res. 1980, 41, 250-254. [PubMed]

58. Perille, A.L.; Matus, R.E. Canine ehrlichiosis in six dogs with persistently increased antibody titers. J. Vet. Intern. Med. 1991, 5, 195-198. [CrossRef] [PubMed]

59. Bartsch, R.C.; Greene, R.T. Post-therapy antibody titers in dogs with ehrlichiosis: Follow-up study on 68 patients treated primarily with tetracycline and/or doxycycline. J. Vet. Intern. Med. 1996, 10, 271-274. [CrossRef] [PubMed]

60. Harrus, S.; Waner, T.; Aizenberg, I.; Bark, H. Therapeutic effect of doxycycline in experimental subclinical canine monocytic ehrlichiosis: Evaluation of a 6-week course. J. Clin. Microbiol. 1998, 36, 2140-2142. [PubMed] 
61. Davidson, D.E.; Dill, G.S.; Tingpalapong, M.; Premabutra, S.; Nguen, P.L.; Stephenson, E.H.; Ristic, M. Prophylactic and therapeutic use of tetracycline during an epizootic of ehrlichiosis among military dogs. J. Am. Vet. Med. Assoc. 1978, 172, 697-700. [PubMed]

62. Kakoma, I.; Carson, C.A.; Ristic, M.; Huxsoll, D.L.; Stephenson, E.H.; Nyindo, M.B. Autologous lymphocyte-mediated cytotoxicity against monocytes in canine ehrlichiosis. Am. J. Vet. Res. 1977, 38, 1557-1559. [PubMed]

63. De Castro, M.B.; Machado, R.Z.; de Aquino, L.P.; Alessi, A.C.; Costa, M.T. Experimental acute canine monocytic ehrlichiosis: Clinicopathological and immunopathological findings. Vet. Parasitol. 2004, 119, 73-86. [CrossRef] [PubMed]

64. Mylonakis, M.E.; Koutinas, A.F.; Breitschwerdt, E.B.; Hegarty, B.C.; Billinis, C.D.; Leontides, L.S.; Kontos, V.S. Chronic canine ehrlichiosis (Ehrlichia canis): A retrospective study of 19 natural cases. J. Am. Anim. Hosp. Assoc. 2004, 40, 174-184. [CrossRef] [PubMed]

65. Codner, E.C.; Roberts, R.E.; Ainsworth, A.G. Atypical findings in 16 cases of canine ehrlichiosis. J. Am. Vet. Med. Assoc. 1985, 186, 166-169. [PubMed]

66. Matus, R.E.; Leifer, C.E.; Hurvitz, A.I. Use of plasmapheresis and chemotherapy for treatment of monoclonal gammopathy associated with Ehrlichia canis infection in a dog. J. Am. Vet. Med. Assoc. 1987, 190, 1302-1304. [PubMed]

67. Harrus, S.; Waner, T.; Weiss, D.J.; Keysary, A.; Bark, H. Kinetics of serum antiplatelet antibodies in experimental acute canine ehrlichiosis. Vet. Immunol. Immunopathol. 1996, 51, 13-20. [CrossRef]

68. Harrus, S.; Waner, T.; Avidar, Y.; Bogin, E.; Peh, H.; Bark, H. Serum protein alterations in canine ehrlichiosis. Vet. Parasitol. 1996, 66, 241-249. [CrossRef]

69. Codner, E.C.; Farris-Smith, L.L. Characterization of the subclinical phase of ehrlichiosis in dogs. J. Am. Vet. Med. Assoc. 1986, 189, 47-50. [PubMed]

70. Reardon, M.J.; Pierce, K.R. Acute experimental canine ehrlichiosis. I. Sequential reaction of the hemic and lymphoreticular systems. Vet. Pathol. 1981, 18, 48-61. [PubMed]

71. Frank, J.R.; Breitschwerdt, E.B. A retrospective study of ehrlichiosis in 62 dogs from north carolina and Virginia. J. Vet. Intern. Med. 1999, 13, 194-201. [CrossRef] [PubMed]

72. Tajima, T.; Rikihisa, Y. Cytokine responses in dogs infected with Ehrlichia canis Oklahoma strain. Ann. N. Y. Acad. Sci. 2005, 1063, 429-432. [CrossRef] [PubMed]

73. Unver, A.; Huang, H.; Rikihisa, Y. Cytokine gene expression by peripheral blood leukocytes in dogs experimentally infected with a new virulent strain of Ehrlichia canis. Ann. N. Y. Acad. Sci. 2006, 1078, 482-486. [CrossRef] [PubMed]

74. Harrus, S.; Waner, T.; Keysary, A.; Aroch, I.; Voet, H.; Bark, H. Investigation of splenic functions in canine monocytic ehrlichiosis. Vet. Immunol. Immunopathol. 1998, 62, 15-27. [CrossRef]

75. Xiong, Q.; Bao, W.; Ge, Y.; Rikihisa, Y. Ehrlichia ewingii infection delays spontaneous neutrophil apoptosis through stabilization of mitochondria. J. Infect. Dis. 2008, 197, 1110-1118. [CrossRef] [PubMed]

76. Dumler, J.S. Anaplasma and Ehrlichia infection. Ann. N. Y. Acad. Sci. 2005, 1063, 361-373. [CrossRef] [PubMed]

77. Prozesky, L. Heartwater. The artificial transmission of cowdria ruminantium in domestic ruminants and mice. Onderstepoort J. Vet. Res. 1987, 54, 277-279. [PubMed]

78. Faburay, B.; Jongejan, F.; Taoufik, A.; Ceesay, A.; Geysen, D. Genetic diversity of Ehrlichia ruminantium in amblyomma variegatum ticks and small ruminants in the gambia determined by restriction fragment profile analysis. Vet. Microbiol. 2008, 126, 189-199. [CrossRef] [PubMed]

79. Allsopp, M.T.; Allsopp, B.A. Extensive genetic recombination occurs in the field between different genotypes of Ehrlichia ruminantium. Vet. Microbiol. 2007, 124, 58-65. [CrossRef] [PubMed]

80. Bezuidenhout, J.D. Natural transmission of heartwater. Onderstepoort J. Vet. Res. 1987, 54, 349-351. [PubMed]

81. Camus, E.; Barre, N. Vector situation of tick-borne diseases in the caribbean islands. Vet. Parasitol. 1995, 57, 167-176. [CrossRef]

82. Collins, N.E.; Pretorius, A.; van Kleef, M.; Brayton, K.A.; Allsopp, M.T.; Zweygarth, E.; Allsopp, B.A. Development of improved attenuated and nucleic acid vaccines for heartwater. Dev. Biol. (Basel) 2003, 114, 121-136. [PubMed] 
83. Pretorius, A.; van Kleef, M.; Collins, N.E.; Tshikudo, N.; Louw, E.; Faber, F.E.; van Strijp, M.F.; Allsopp, B.A. A heterologous prime/boost immunisation strategy protects against virulent e. Ruminantium welgevonden needle challenge but not against tick challenge. Vaccine 2008, 26, 4363-4371. [CrossRef] [PubMed]

84. Deem, S.L.; Norval, R.A.; Donachie, P.L.; Mahan, S.M. Demonstration of vertical transmission of cowdria ruminantium, the causative agent of heartwater, from cows to their calves. Vet. Parasitol. 1996, 61, 119-132. [CrossRef]

85. Prozesky, L.; Du Plessis, J.L. Heartwater. The development and life cycle of cowdria ruminantium in the vertebrate host, ticks and cultured endothelial cells. Onderstepoort J. Vet. Res. 1987, 54, 193-196. [PubMed]

86. Du Plessis, J.L.; Malan, L. Problems with the interpretation of epidemiological data in heartwater: A study on 23 farms. Onderstepoort J. Vet. Res. 1987, 54, 427-433. [PubMed]

87. Bezuidenhout, J.D.; Olivier, J.A.; Gruss, B.; Badenhorst, J.V. The efficacy of alternative routes for the infection or vaccination of animals with cowdria ruminantium. Onderstepoort J. Vet. Res. 1987, 54, 497-506. [PubMed]

88. Yunker, C.E. Heartwater in sheep and goats: A review. Onderstepoort J. Vet. Res. 1996, 63, 159-170. [PubMed]

89. Uilenberg, G. Heartwater (cowdria ruminantium infection): Current status. Adv. Vet. Sci Comp. Med. 1983, 27, 427-480. [PubMed]

90. Loftis, A.D.; Mixson, T.R.; Stromdahl, E.Y.; Yabsley, M.J.; Garrison, L.E.; Williamson, P.C.; Fitak, R.R.; Fuerst, P.A.; Kelly, D.J.; Blount, K.W. Geographic distribution and genetic diversity of the Ehrlichia sp. From panola mountain in amblyomma americanum. BMC Infect. Dis. 2008, 8, 54. [CrossRef] [PubMed]

91. Reeves, W.K.; Loftis, A.D.; Nicholson, W.L.; Czarkowski, A.G. The first report of human illness associated with the panola mountain Ehrlichia species: A case report. J. Med. Case Rep. 2008, 2, 139. [CrossRef] [PubMed]

92. Yabsley, M.J.; Loftis, A.D.; Little, S.E. Natural and experimental infection of white-tailed deer (odocoileus virginianus) from the united states with an Ehrlichia sp. Closely related to Ehrlichia ruminantium. J. Wildl. Dis. 2008, 44, 381-387. [CrossRef] [PubMed]

93. Loftis, A.D.; Levin, M.L.; Spurlock, J.P. Two usa Ehrlichia spp. Cause febrile illness in goats. Vet. Microbiol. 2008, 130, 398-402. [CrossRef] [PubMed]

94. Allsopp, M.T.; Allsopp, B.A. Novel ehrlichia genotype detected in dogs in South Africa. J. Clin. Microbiol. 2001, 39, 4204-4207. [CrossRef]

95. Allsopp, M.T.; Louw, M.; Meyer, E.C. Ehrlichia ruminantium: An emerging human pathogen? Ann. N. Y. Acad. Sci. 2005, 1063, 358-360. [CrossRef] [PubMed]

96. Winslow, G.M.; Yager, E.; Shilo, K.; Collins, D.N.; Chu, F.K. Infection of the laboratory mouse with the intracellular pathogen Ehrlichia chaffeensis. Infect. Immun. 1998, 66, 3892-3899. [PubMed]

97. Byrom, B.; Obwolo, M.; Barbet, A.F.; Mahan, S.M. A polarized th1 type immune response to cowdria ruminantium infection is detected in immune dba/2 mice. J. Parasitol. 2000, 86, 983-992. [CrossRef]

98. Byrom, B.; Barbet, A.F.; Obwolo, M.; Mahan, S.M. CD8(+) T cell knockout mice are less susceptible to cowdria ruminantium infection than athymic, CD4(+) T cell knockout, and normal c57bl/6 mice. Vet. Parasitol. 2000, 93, 159-172. [CrossRef]

99. Sotomayor, E.A.; Popov, V.L.; Feng, H.M.; Walker, D.H.; Olano, J.P. Animal model of fatal human monocytotropic ehrlichiosis. Am. J. Pathol. 2001, 158, 757-769. [CrossRef]

100. Li, J.S.; Chu, F.; Reilly, A.; Winslow, G.M. Antibodies highly effective in scid mice during infection by the intracellular bacterium Ehrlichia chaffeensis are of picomolar affinity and exhibit preferential epitope and isotype utilization. J. Immunol. 2002, 169, 1419-1425. [CrossRef] [PubMed]

101. Ganta, R.R.; Wilkerson, M.J.; Cheng, C.; Rokey, A.M.; Chapes, S.K. Persistent Ehrlichia chaffeensis infection occurs in the absence of functional major histocompatibility complex class II genes. Infect. Immun. 2002, 70, 380-388. [CrossRef] [PubMed]

102. Olano, J.P.; Wen, G.; Feng, H.M.; McBride, J.W.; Walker, D.H. Histologic, serologic, and molecular analysis of persistent ehrlichiosis in a murine model. Am. J. Pathol. 2004, 165, 997-1006. [CrossRef]

103. Feng, H.M.; Walker, D.H. Mechanisms of immunity to Ehrlichia muris: A model of monocytotropic ehrlichiosis. Infect. Immun. 2004, 72, 966-971. [CrossRef] [PubMed]

104. Ganta, R.R.; Cheng, C.; Wilkerson, M.J.; Chapes, S.K. Delayed clearance of Ehrlichia chaffeensis infection in CD4+ T-cell knockout mice. Infect. Immun. 2004, 72, 159-167. [CrossRef] [PubMed]

105. Ismail, N.; Stevenson, H.L.; Walker, D.H. Role of tumor necrosis factor alpha (tnf-alpha) and interleukin-10 in the pathogenesis of severe murine monocytotropic ehrlichiosis: Increased resistance of tnf receptor p55and p75-deficient mice to fatal ehrlichial infection. Infect. Immun. 2006, 74, 1846-1856. [CrossRef] [PubMed] 
106. Ismail, N.; Crossley, E.C.; Stevenson, H.L.; Walker, D.H. Relative importance of T-cell subsets in monocytotropic ehrlichiosis: A novel effector mechanism involved in ehrlichia-induced immunopathology in murine ehrlichiosis. Infect. Immun. 2007, 75, 4608-4620. [CrossRef] [PubMed]

107. Ganta, R.R.; Cheng, C.; Miller, E.C.; McGuire, B.L.; Peddireddi, L.; Sirigireddy, K.R.; Chapes, S.K. Differential clearance and immune responses to tick cell-derived vs. macrophage culture-derived Ehrlichia chaffeensis in mice. Infect. Immun. 2007, 75, 135-145. [CrossRef] [PubMed]

108. Bitsaktsis, C.; Nandi, B.; Racine, R.; MacNamara, K.C.; Winslow, G. T-cell-independent humoral immunity is sufficient for protection against fatal intracellular Ehrlichia infection. Infect. Immun. 2007, 75, 4933-4941. [CrossRef] [PubMed]

109. MacNamara, K.C.; Jones, M.; Martin, O.; Winslow, G.M. Transient activation of hematopoietic stem and progenitor cells by ifn $\gamma$ during acute bacterial infection. PLoS ONE 2011, 6, e28669. [CrossRef] [PubMed]

110. MacNamara, K.C.; Racine, R.; Chatterjee, M.; Borjesson, D.; Winslow, G.M. Diminished hematopoietic activity associated with alterations in innate and adaptive immunity in a mouse model of human monocytic ehrlichiosis. Infect. Immun. 2009, 77, 4061-4069. [CrossRef] [PubMed]

111. Zhang, Y.; Jones, M.; McCabe, A.; Winslow, G.M.; Avram, D.; MacNamara, K.C. Myd88 signaling in CD4 T cells promotes ifn- $\gamma$ production and hematopoietic progenitor cell expansion in response to intracellular bacterial infection. J. Immunol. 2013, 190, 4725-4735. [CrossRef] [PubMed]

112. Yates, J.L.; Racine, R.; McBride, K.M.; Winslow, G.M. T cell-dependent igm memory B cells generated during bacterial infection are required for igg responses to antigen challenge. J. Immunol. 2013, 191, 1240-1249. [CrossRef] [PubMed]

113. Jones, R.S.; Minogue, A.M.; Fitzpatrick, O.; Lynch, M.A. Inhibition of jak2 attenuates the increase in inflammatory markers in microglia from app/ps1 mice. Neurobiol. Aging 2015, 36, 2716-2724. [CrossRef] [PubMed]

114. Racine, R.; Jones, D.D.; Chatterjee, M.; McLaughlin, M.; Macnamara, K.C.; Winslow, G.M. Impaired germinal center responses and suppression of local igg production during intracellular bacterial infection. J. Immunol. 2010, 184, 5085-5093. [CrossRef] [PubMed]

115. Ghose, P.; Ali, A.Q.; Fang, R.; Forbes, D.; Ballard, B.; Ismail, N. The interaction between il-18 and il-18 receptor limits the magnitude of protective immunity and enhances pathogenic responses following infection with intracellular bacteria. J. Immunol. 2011, 187, 1333-1346. [CrossRef] [PubMed]

116. Racine, R.; McLaughlin, M.; Jones, D.D.; Wittmer, S.T.; MacNamara, K.C.; Woodland, D.L.; Winslow, G.M. Igm production by bone marrow plasmablasts contributes to long-term protection against intracellular bacterial infection. J. Immunol. 2011, 186, 1011-1021. [CrossRef] [PubMed]

117. Habib, S.; El Andaloussi, A.; Hisham, A.; Ismail, N. Nk cell-mediated regulation of protective memory responses against intracellular ehrlichial pathogens. PLoS ONE 2016, 11, e0153223. [CrossRef] [PubMed]

118. Stevenson, H.L.; Jordan, J.M.; Peerwani, Z.; Wang, H.Q.; Walker, D.H.; Ismail, N. An intradermal environment promotes a protective type-1 response against lethal systemic monocytotropic ehrlichial infection. Infect. Immun. 2006, 74, 4856-4864. [CrossRef] [PubMed]

119. Saito, T.B.; Thirumalapura, N.R.; Shelite, T.R.; Rockx-Brouwer, D.; Popov, V.L.; Walker, D.H. An animal model of a newly emerging human ehrlichiosis. J. Infect. Dis. 2015, 211, 452-461. [CrossRef] [PubMed]

120. Saito, T.B.; Walker, D.H. A tick vector transmission model of monocytotropic ehrlichiosis. J. Infect. Dis. 2015, 212, 968-977. [CrossRef] [PubMed]

121. Ismail, N.; Soong, L.; McBride, J.W.; Valbuena, G.; Olano, J.P.; Feng, H.M.; Walker, D.H. Overproduction of tnf-alpha by CD8+ type 1 cells and down-regulation of ifn-gamma production by CD4+ th1 cells contribute to toxic shock-like syndrome in an animal model of fatal monocytotropic ehrlichiosis. J. Immunol. 2004, 172, 1786-1800. [CrossRef] [PubMed]

122. Kuriakose, J.A.; Miyashiro, S.; Luo, T.; Zhu, B.; McBride, J.W. Ehrlichia chaffeensis transcriptome in mammalian and arthropod hosts reveals differential gene expression and post transcriptional regulation. PLOS ONE 2011, 6, e24136. [CrossRef] [PubMed]

123. Yager, E.; Bitsaktsis, C.; Nandi, B.; McBride, J.W.; Winslow, G. Essential role for humoral immunity during Ehrlichia infection in immunocompetent mice. Infect. Immun. 2005, 73, 8009-8016. [CrossRef] [PubMed]

124. MacNamara, K.C.; Oduro, K.; Martin, O.; Jones, D.D.; McLaughlin, M.; Choi, K.; Borjesson, D.L.; Winslow, G.M. Infection-induced myelopoiesis during intracellular bacterial infection is critically dependent upon ifn- $\gamma$ signaling. J. Immunol. 2011, 186, 1032-1043. [CrossRef] [PubMed] 
125. Rudoler, N.; Baneth, G.; Eyal, O.; van Straten, M.; Harrus, S. Evaluation of an attenuated strain of Ehrlichia canis as a vaccine for canine monocytic ehrlichiosis. Vaccine 2012, 31, 226-233. [CrossRef] [PubMed]

126. Sebatjane, S.I.; Pretorius, A.; Liebenberg, J.; Steyn, H.; Van Kleef, M. In vitro and in vivo evaluation of five low molecular weight proteins of Ehrlichia ruminantium as potential vaccine components. Vet. Immunol. Immunopathol. 2010, 137, 217-225. [CrossRef] [PubMed]

(c) 2016 by the authors; licensee MDPI, Basel, Switzerland. This article is an open access article distributed under the terms and conditions of the Creative Commons Attribution (CC-BY) license (http://creativecommons.org/licenses/by/4.0/). 